\title{
Does Total Quality Management Influence Teacher Quality? An Emperical Anaysis.
}

\author{
Mohd Rahimi A Rahman, Mohamed Yusoff Mohd Nor \& Jamalul Lail Abdul \\ Wahab
}

To Link this Article: http://dx.doi.org/10.6007/IJARBSS/v11-i1/8381

DOI:10.6007/IJARBSS/v11-i1/8381

Received: 10 November 2020, Revised: 11 December 2020, Accepted: 30 December 2021

Published Online: 20 January 2021

In-Text Citation: (Rahman et al., 2020)

To Cite this Article: Rahman, M. R. A., Nor, M. Y. M., \& Wahab, J. L. A. (2020). Does Total Quality Management Influence Teacher Quality? An emperical anaysis. International Journal of Academic Research in Business and Social Sciences, 11(1), 250-260.

\section{Copyright: (c) 2021 The Author(s)}

Published by Human Resource Management Academic Research Society (www.hrmars.com)

This article is published under the Creative Commons Attribution (CC BY 4.0) license. Anyone may reproduce, distribute, translate and create derivative works of this article (for both commercial and non-commercial purposes), subject to full attribution to the original publication and authors. The full terms of this license may be seen at: http://creativecommons.org/licences/by/4.0/legalcode

Vol. 11, No. 1, 2021, Pg. 250 - 260

Full Terms \& Conditions of access and use can be found at http://hrmars.com/index.php/pages/detail/publication-ethics 


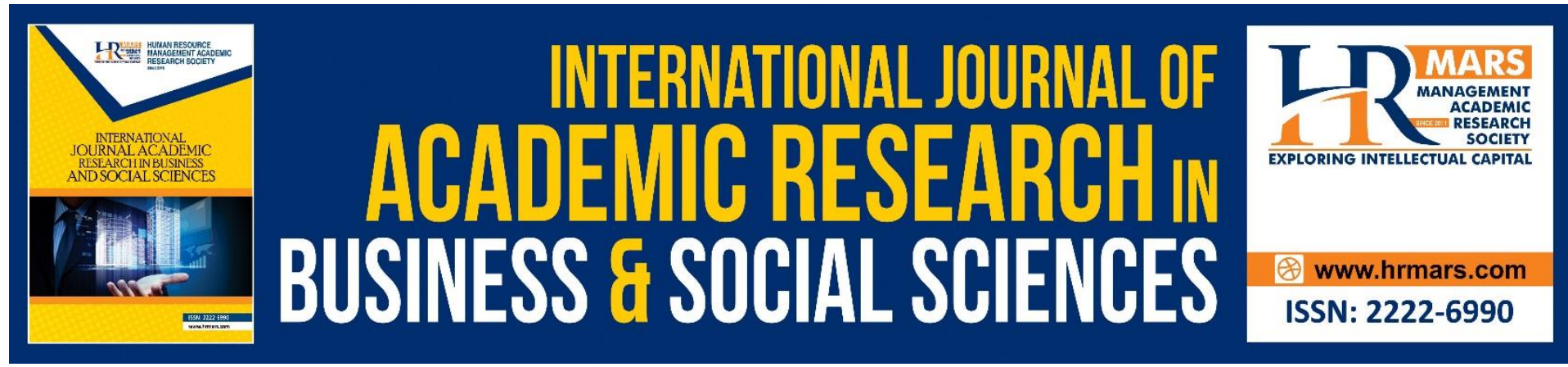

\title{
Does Total Quality Management Influence Teacher Quality? An emperical anaysis.
}

\author{
Mohd Rahimi A Rahman, Mohamed Yusoff Mohd Nor \& \\ Jamalul Lail Abdul Wahab
}

Faculty of Education, National University of Malaysia, 43600 Bangi, Selangor, Malaysia

\begin{abstract}
This study is aimed to explain the examines the influence of total quality management on the teacher quality in secondary schools. This study used cross-sectional surveys to collect data from 423 secondary school teachers from all over Malaysia. Data were collected using questionnaires adapted from Total Quality Management Instruments (Zhang, Waszink, \& Wijngaard, 2000), Multi-Factor Leadership Questionnare (Avalio \& Bass, 2004) and Malaysian Teacher Standards Instruments (MOE, 2008). This study used Multiple Regression to determine the relationship between variables. This study uses simple random sampling procedures and proportional random sampling. The results show that leadership are the best practices of total quality management that influence teacher quality. Therefore, the practice of rewarding and implementing charismatic leadership styles is encouraged to improve teacher quality in Malaysian secondary school.
\end{abstract}

Keywords: Total Quality Management, Teacher Quality, Secondary School.

\section{Introduction}

Quality teachers are very important in the education system. Thus, teacher quality is an aspect that needs to be considered to achieve a teacher's self-perfection in educating students in school (Nilsen, Trude \& Gustafsson, 2016). Teachers' quality can also symbolise a teacher's level of job satisfaction (Don, Azizah \& Yaakob, 2014). High teachers' quality could increase their commitment in carrying out their responsibilities, gaining the necessary knowledge and skills, increase their interest in their work, carrying out their responsibility sincerely without any coercion and stay loyal to their work (MOE, 2016). Consequently, quality teachers will be able to implement the national education policy effectively and will strive to achieve their school's mission and vision (Shahril, 2005).

The field of education is now thriving in line with the development of advanced technology to produce a society that is spiritually, physically, emotionally, and intellectually balance, responsible, able to achieve their personal well-being and contribute to the country's harmony and prosperity (Nordin \& Othman, 2008). This amplifies to need to highlight teachers' quality in addressing the increasing teachers' workload. The presence of quality teachers is one of the important elements in improving teaching and learning effectiveness in the education system, specifically in schools. It was argued that this process requires teachers who are creative, efficient, highly motivated, and farsighted. (Mau, Ellsworth, \& 
Hawley, 2008). All these elements could be achieved when teachers have a high level of professional and personal quality. Based on the argument above, having high quality teachers is imperative in ensuring the country's aspiration to become a developed and educated country could be achieved. Subsequently, quality teachers will demonstrate the best work performance which in turn, increases a school's productivity, capability, and effectiveness (Hanushek \& Rivkin, 2006). This ultimately, helps produce a successful future generation. On the other hand, the notion of quality teachers differs across individual teachers, thus, it is difficult the measure and set a benchmark for teachers' quality due to the different responsibilities, burdens, problems, exposures and experiences of each teacher (Mau et al. 2008).

\section{Problem Statement}

Teachers play an important role in producing future citizens with commendable personality and able to serve the country. A teacher's works are not limited to conducting lessons as set in the syllabus. They are also responsible for other duties such as collecting fees, handling the curriculum work, coordinating co-curricular activities, organizing teacher club activities and other tasks that can affect their quality of work and professionalism.

Based on the initial report of the Committee to Review the Duties and Responsibilities of Teachers published in 2005, 12.7 per cent of teachers' time are spent coordinating out-of-the class activities, including co-curriculum activities. Moreover, teachers spent 8.9 per cent of their time managing matters related to student affairs, 1.2 per cent of their time for hostel management, 4.3 per cent for school management, 2.4 per cent for school financial matters, 1.1 per cent of their time for training and community and lastly, 0.1 per cent to help manage and repair physical infrastructure in schools.

The Committee to Review the Duties and Responsibilities of Teachers also conducted a further study in 2007 and found that a teacher in Malaysia uses an average of 66.24 hours a week to perform duties and responsibilities as an educator (MOE, 2007). This number of hours exceeds the average working hours recommended by the International Labour Organisation (ILO), which is 45 hours per week. The report also states that teachers are often burdened with various tasks consisting of curriculum, and co-curriculum activities, community relations and staff development, maintaining school's physical infrastructure, administrative tasks, financial and student affairs matters as well as hostel management. For instance, in term of curriculum affairs, a teacher is required to perform different tasks inside and outside of the classroom, including implementation of teaching and learning sessions, lesson planning, preparation of teaching materials, assessment, additional classes and other (MOE, 2007).

The result of a survey on Teachers' Workload based on different aspects conducted by the Special Committee to Address Teacher Workload was presented in the Ministry of Education Malaysia's letter number 20, 2012. According to the report out of 17 respondents, 47 per cent were allocated more than 29 hours teaching hours per week while 53 per cent have a work hours of 66 hours per week, including their Teaching and Learning (T\&L) sessions. All 17 teachers stated that there is no specific list of duties and responsibilities for teachers and that they are unclear on their weekly working hours. Furthermore, all of the respondents stated that teachers are highly burdened clerical work and teachers lack the skills to train students for co-curricular activities. 
Good school quality management practices could lead to effective schools without relying on of principals' effective leadership capabilities (Davies \& Burnham, 2010). As principals come and go, the quality of a school and its teachers can still be maintained through quality management practices. This is because all quality elements schools can be systematically formed including quality teachers and can produce successful students in every aspect (Davies \& Burnham, 2010). Effective quality management practices will ensure that teachers and school staff are able to carry out their daily tasks and responsibilities according to the school quality management guidelines. Subsequently, this could produce quality works in every aspect and subsequently, lead to highly satisfied students.

Quality management practices are being implemented continuously to improve the public service in Malaysia to ensure the effective delivery of government services. These practices include Total Quality Management practices, Innovative and Creative Groups, Quality Improvement Groups, and Quality School Management System. However, the implementation of quality management is still poorly implemented at the school level (Rahim, Rahman \& Daud, 2012). This phenomenon occurs because schools' administrators and teachers still do not properly understand the importance of total quality management. It was found that school administrators are unable to identify the suitable quality management practices to be implemented in schools. Furthermore, this lack of understanding has led to schools' management practices to produce low quality teachers and many are staying in their comfortable zone. There is a concern that the deteriorating quality management in schools will affect teachers' quality and their ability to implement education policies if stakeholders do not place serious emphasis on quality in education.

Based on the issues, problems and challenges discussed earlier, there is still some room to study the gaps in teacher quality by using a more comprehensive and effective approach, specifically total quality management practices. Thus, this study strives to increase the understanding towards the impact of total quality management practices on teacher quality.

\section{Literature Review}

Total Quality Management refers to the quality management practices practiced in school management to improve teacher quality, school effectiveness and students' holistic development. Total quality management practices encompass students' focus, administrative leadership, teaches' involvement, continuous improvement, rewards, and training, as well as education and training.

The customer focus in this study refers to the school's focus on fostering students' long-term holistic development through compiling complaints related to the schools' provision of quality services and education from students and parents. In this light, schools should also address complaints from students and parents to ensure customer satisfaction. A survey of student achievement is conducted annually to ensure the provision of quality services and education. The school collects suggestions from parents on how to improve the students' and school's achievement to guarantee the quality of education to are provided for the students, as stated in the e Malaysian Education Quality Standards (SKPM). If a school wants to obtain good quality management, it is important for it to understand and fulfil the students' needs of (Ishikawa, 1985). A successful school could identify students' needs and prioritising them to achieve the school's goals. The main factor of success in quality management is maintaining 
good relationships with students who are the school's main customers (Zhang et. Al., 2000). This good relationship can be implemented by identifying the students' needs and receiving students' feedback to meet their needs and increase their satisfaction with the school. Students should be involved in the policy making process, as well as in designing the learning in schools (Flynn, Schroeder \& Sakakibaba, 1994). Students should be included in every stage of education planning, including the teaching and learning process in the classroom (Ko \& Chung, 2014). The main measure of school achievement is the students' satisfaction and achievement, as well as the fulfilment of students' needs. In this light, students' satisfaction refers to their achievement in school which will determine the success or failure of a school (Kanji \& Asher, 1993).

The factor of leadership refers to the active involvement of school administrators in quality management and the implementation of the school improvement practices in improving a school's performance. Administrators also need to have knowledge of quality management concepts and skills to encourage teachers' involvement and empowerment them in solving quality-related problems as well as providing adequate resources to teachers and other school staff. School Administrators also need to discuss the issue of quality in education and focus on the quality of services in accordance with the Malaysian Education Quality Standards to ensure the success of the school in the long run. Therefore, school administration leadership is an important factor in producing goals, values and systems that guide the continuous performance improvement. Founders of quality management, such as Deming (1986) also emphasised the importance of leadership in the implementation of Total Quality Management. Weaknesses in administrative commitment in schools will lead to failure to implement quality management practices in schools (Brown, Hitchcook \& Willard, 1994). An organisation's achievement of high quality starts from the leader's commitment to fulfil the organisational goals, high quality of service and high leadership commitment. Many past studies have proven that top management support for quality is a key factor in quality improvement in organisations (Zhang et al., 2000).

Employee Participants, in this study, refers to the school's role to encourage teachers to be actively involved in quality-related activities in schools. The school also needs to conduct a quality inspection cycle in accordance with the Malaysian Education Quality Standards and put forward suitable recommendations to the teachers after the assessment. The school encourages teachers' commitment to achieve success through their own problem-solving and reporting work problems that cannot be solved. The involvement of teachers in quality improvement activities will provide new knowledge to them. They will gain benefit in terms of quality and are able to solve problems related to quality independently. Teachers' involvement in quality management can change their behaviour in school and could be an inspiration in quality improvement in schools (Juran \& Gryna, 1993).

In this study, continuous improvement, refers to the process of quality control and school improvement in terms of clear work instructions, provision of information on accurate and efficient internal and financial operations, and scheduled maintenance of school infrastructure. Apart from that, the school also evaluates teachers' performance and efficiency through statistical quality evaluation according to the Malaysian Education Quality Standards, as well as post-mortem activities (PDCA) in controlling and improving the quality of teachers, education, and school services. In this light, continuous improvement is one of 
the important factors in increasing the success and reduction of the failure in an organisation (Juran \& Gryna, 1993). Juran and Gryna (1993) defined continuous improvement as a holistic process and innovation performed continuously. Schools need to make continuous and effective improvements to ensure the effectiveness of quality management in school. Such continuous improvement requires the evaluation of current processes and the implementation of quality management practices. Quality assessment begins with identifying and addressing quality issues (Juran \& Gryna, 1993).

Another factor in this study is reward. It refers to the reward and recognition given by the school to the teacher as an appreciation of the quality improvement efforts they shown. The school also needs to improve the rewards and recognition system so that it will be clear to the teachers and should be based on teachers' quality improvement to motivate teachers to works towards quality improvement in schools. In other words, rewards and recognitions, such as promotion and financial rewards. should be given based on teachers' quality and excellence to encourage them to commit to quality improvement. Dale and Plunkett (1990) stated that among the important factors in quality improvement programs is the appreciation given by an individual, division, or department in an organization. Thus, schools need to implement a reward system encompassing quality and student satisfaction to support teacher quality improvement efforts, (student achievement and achievement) (Brown et. al., 1994).

Education in this study refers to the school's efforts to encourage teachers to provide education and training, as well as provide the resources needed by teachers to facilitate educational and training activities to improve teachers' quality. Schools also need to make teachers aware of the importance of quality education. This could be done through the provision on quality management practices training and specific job skills development. $A$ teacher who received quality training could become a valuable person in the school. In this regard, education and training are important in the continuous improvement of teachers and schools (Deming, 1986). Numerous researchers also support that education and training are important elements in the successful implementation of quality management (Mann, 1992).

Teachers' quality in this study refers to the quality of teachers' personal and professional quality. These aspects could be measured through teachers' professionalism, teachers' knowledge and understanding as well as teaching and learning skills to improve students' achievement and performance. Teachers' professionalism entails the standards, competencies and professional values that should be passed by a teacher. These elements could be divided to three main domains, namely the personal, professional and the social domain. According to MOE (2008), these practices have been formulated based on the culture of teaching, values in the school curriculum, values and ethics in the public service.

The factor of knowledge and understanding focuses on teachers' standards and competencies in terms of their knowledge and understanding of their subject of specialisation, education as well as curriculum and co-curriculum elements. Teachers who master and understand the knowledge will be able to increase their professionalism, can perform tasks efficiently and can become a creative and innovative person as they expand their existing knowledge (MOE, 2008). 
Lastly, teaching and learning skills emphasise teachers' standards and competencies in terms of their mastery of teaching and learning skills which highlight their ability to plan, implement and evaluate academic and co-curricular teaching and learning.

\section{Conceptual Framework}

The study's conceptual framework, as shown in Figure 1 provides an overview of the relationship between the independent variable (total quality management) and dependent variable (teacher quality). This study's conceptual framework is based on an extended version of Social Cognitive Career Theory by Lent and Brown (2006). The researchers have extended the Social Cognitive Career Theory and developed an individual achievement model (Lent \& Brown, 2006). This model was developed understand the factors influencing teachers' careers in education and vocational fields (Lent \& Brown, 2006). This extended model also emphasizes the impact of behaviour and the environment on the individual's achievement and selfdevelopment (Lent \& Brown, 2006). The main framework of this study is supported by two main models, namely the Total Quality Management Model (Oakland, 2014) and the Malaysian Teacher Standard Model (MOE, 2008).

\begin{tabular}{|l|l|}
\hline \multicolumn{1}{|c|}{ TOTAL QUALITY } \\
MANAGEMENT \\
(Oakland 2014)
\end{tabular} \mid $\begin{gathered}\text { TEACHER QUALITY } \\
\text { The Malaysian Teacher } \\
\text { Standards Model } \\
\text { - Customer focus } \\
\begin{array}{l}\text { - Leadership } \\
\text { - Employee Participants } \\
\text { - Continuous Improvement } \\
\text { - Reward }\end{array}\end{gathered}$

Figure 1: Influence of Total Quality Management on Teacher Quality

\section{Methodology \\ Research Design}

This study used the cross-sectional survey method to obtain the research data. The data were collected at a specific time and the respondents consist of secondary school teachers from across Malaysia. Statistical tests were used to analyse the data as this study involved numerical data. This study is a descriptive study where it examined the influence of total quality management practices towards teachers' quality. This study describes the phenomenon by analysing the data obtained from the questionnaire. The information obtained was classified according to the specified aspects and interpreted quantitatively. The statistical analysis used answer the research question are descriptive statistics and multiple regression.

The data measurement also involves testing the theory's reliability and validity, constructing facts and stating the relationship between variables. Reliability and validity are very important in this study to ensure that the instrument could accurately and consistently measure the variables. This study used simple random sampling to ensures that each unit or 
subject in the population has the same opportunity to be selected as the respondent of this study. Thus, it was used to select the states and teachers involved in this study.

\section{Sample}

The population of this study is teachers working in national secondary schools. These teachers have different responsibilities and workloads from those teaching in other types schools. In this light, students in national secondary schools have diverse behaviours and backgrounds and this diversity also influences the quality of teachers in these schools. In determine the appropriate number of samples, the researcher considered several aspects including the study design, research procedures and statistical analysis. Subsequently, the number of samples was set at 423. Due to the sheer number of teachers across Malaysia, sampling was done in five stages. Which are selecting schools at the zone level, at the state level, determining the distribution of schools, selecting schools and finally, selecting teacher involved.

\section{Instrument}

The study's data were collected using a questionnaire adapted from the Total Quality Management Instrument (Zhang et. al., 2000) and the Malaysian Teacher Standards Instrument (MOE, 2008). This study evaluated construct validity and content validity to determine whether the questionnaire could measure the study's concepts. Item Scale Correlation and Internal Consistency (Cronbach's Alpha) methods were used to measure the reliability.

Table 1: Details of the Questionnaire's items based on dimension

\begin{tabular}{|c|c|c|c|c|}
\hline Part & Variable & Dimension & Total Item & Cronbach-Alpha ( $\alpha)$ \\
\hline \multirow[t]{3}{*}{$A$} & Demography & Gender & 1 & - \\
\hline & & Education level & 1 & - \\
\hline & & Type of school & 1 & - \\
\hline \multirow[t]{6}{*}{ B } & Total Quality & Customer Focus & 6 & .847 \\
\hline & Management & Leadership & 8 & .876 \\
\hline & & Employee Participants & 8 & .768 \\
\hline & & Continuous Improvement & 9 & .915 \\
\hline & & Reward & 6 & .874 \\
\hline & & Education & 6 & .879 \\
\hline \multirow[t]{3}{*}{$\mathrm{C}$} & Teachers' & Teaching Professionalism & 26 & .966 \\
\hline & Quality & Knowledge and understanding & 21 & .962 \\
\hline & & Teaching and learning skills & 24 & .964 \\
\hline
\end{tabular}

\section{Data Analysis}

The data collected were analysed using the SPSS (Statistical Package for the Social Sciences) software. SPSS is a specialised computer software which analyses statistically collected data and information. This study used several statistical analysis techniques include descriptive statistics and multiple regression analysis to identify the relationship between the variables in this study, and to answer the research questions through analysing the statistical data collected. Before performing a more detailed data analysis in more detail, the data were screened by using Exploratory Data Analysis (EDA) first. 


\section{Result}

The results showed that a total of 203 (48\%) male teachers and 220 (52\%) female teachers were involved in this study. Most of the respondents $(\mathrm{N}=322,76.1 \%)$ have a bachelor's degree while 101 or $23.9 \%$ of the respondents have Master and Doctor of Philosophy. The number of teachers teaching in urban schools is 209 people $(49.4 \%)$ while $214(50.6 \%)$ of the teachers are teaching in rural schools.

Table 2: Model Summary for Total Quality Management and Teacher Quality

\begin{tabular}{llllll}
\hline Model & $\mathrm{R}$ & R Square & Adjusted R Square & $\begin{array}{c}\text { Std. Error of the } \\
\text { Estimated }\end{array}$ & \\
\hline 1 & $.947^{\mathrm{a}}$ & .896 & .895 & .10497 & \\
\hline
\end{tabular}

a. Predictors: (Constant): Customer Focus, Leadership, Employee Participants, Continuous Improvement, Reward, Education

b. Dependent Variable: Teacher Quality

Table 3: ANOVA for Total Quality Management and Teacher Quality

\begin{tabular}{lllllll}
\hline Model & & Sum of Squares & $\mathrm{df}$ & Mean Square & $\mathrm{F}$ & Sig. \\
\hline \multirow{3}{*}{1} & Regression & 39.557 & 6 & 6.593 & 598.364 & $.000^{\mathrm{b}}$ \\
& Residual & 4.583 & 416 & .013 & & \\
& Total & 44.140 & 422 & & & \\
\hline
\end{tabular}

a. Dependent Variable: Teacher Quality

b. Predictors: (Constant): Customer Focus, Leadership, Employee Participants, Continuous Improvement, Reward, Education

Table 4: Coefficients for Total Quality Management and Teacher Quality

\begin{tabular}{|c|c|c|c|c|c|}
\hline \multirow[t]{2}{*}{ Model } & \multicolumn{2}{|c|}{$\begin{array}{l}\text { Unstandardized } \\
\text { Coefficients }\end{array}$} & \multirow{2}{*}{$\begin{array}{l}\text { Standardized } \\
\text { Coefficients } \\
\text { Beta }\end{array}$} & \multirow[t]{2}{*}{$t$} & \multirow[t]{2}{*}{ Sig. } \\
\hline & $\mathrm{B}$ & Std. Error & & & \\
\hline (Constant) & .760 & .057 & & 13.254 & .000 \\
\hline Customer Focus & .032 & .021 & .050 & 1.543 & .124 \\
\hline Leadership & .179 & .021 & .286 & 8.429 & .000 \\
\hline Employee Participants & .097 & .016 & .127 & 6.159 & .000 \\
\hline Continuous Improvement & .149 & .022 & .216 & 6.889 & .000 \\
\hline Reward & .168 & .014 & .231 & 12.448 & .000 \\
\hline Education & .178 & .020 & .261 & 8.907 & .000 \\
\hline
\end{tabular}

a. Dependent Variable: Teacher Quality

The influences of total quality management factors, which encompass customer focus, leadership, employee participants, continuous improvement, reward and education, on the quality of teachers in schools, are shown in Table 4. Leadership, employee participants, continuous improvement, rewards and education show a p value of .000 , which is $.05(p<.05)$. Meanwhile, customer focus has a sig value of .124, which exceeds .05 ( $p>.05)$. Thus, only leadership, employee participants, continuous improvement, rewards, and education have a significant influence on the quality of teachers. In the meantime, as shown by the significant value of the five significant practices, leadership is the total quality management element that that has the most influence on the quality of teachers with highest Beta value of .17, compared to the Beta value for other factors of total quality management. 
In general, the influence of total quality management variables on teacher quality can be obtained through regression equation as shown below:

$$
Y=.760+.179\left(X_{2}\right)+.097\left(X_{3}\right)+.149\left(X_{4}\right)+.168\left(X_{5}\right)+.178\left(X_{6}\right)+e
$$

\section{Contribution}

It is hoped that this study can be a guideline and the first step for the ministry's effort in implementing quality management practices in Malaysian schools. This effort could ensure that the Malaysian education system, especially at the secondary school level could progress in line with the country's aspiration to become a developed country. This quality education management system will allow Malaysia to provide a world-class education system to its citizens. In addition, schools' principals can use this study as a guide on how to become an effective leader and manage quality management system. Principals should choose leadership styles that emphasise on aspects of quality management to support the implementation of total quality management practices in schools.

\section{Conclusion}

In conclusion, the quality of teachers is a very significant aspect that should be emphasised to ensure that our schools could effectively produce highly performing students. Thus, total quality management practices need to be implemented effectively in schools, especially at the secondary school level. All parties, including teachers, principals and ministries need to be aware of teachers' quality development so that they will be updated with the current education system. Teachers' quality should be prioritised as the education system we have now is increasingly challenging and teachers are increasingly burdened with different responsibilities. Teachers should not be too comfortable with what they have now, and constantly update their knowledge and skills. Teacher should also increase their efforts to develop the quality of teachers, especially in terms of instilling the values of the teaching profession and improving their knowledge and understanding as well as their teaching and learning skills. Thus, teacher quality can be enhanced through focusing on several important aspects in school, including the management system and principal leadership. Schools can implement effective total quality management practices as these practices guide teacher to perform their duties tasks effectively based on the set standards. Meanwhile, a principal can be a role model and a leader who helps teachers and other school staff by implementing quality leadership and shoulder his responsibilities effectively to achieve the targeted goals.

\section{Reference}

Avolio, B. J., \& Bass, B. M. (2004). Multifactor leadership questionnaire, manual and sampler set (3rd ed.). Mind Garden: Redwood City, CA.

Brown, M. G., Hitchcook, D. E., \& Willard, M. L. (1994). Why TQM fails and what to do about it. Irwin, Burr Ridge: Illinois.

Dale, B. G., \& Plunkett, J. J. (1990). Managing quality. Philip Allan: New York.

Davies, B., \& Burnham, J. W. (2010). Reengineering and total quality in school. Pearson Education: Essex, UK.

Deming, W. E. (1986). Out of Crisis. Massachusetts Institute of Technology. Centre of Advanced Engineering Study. Cambridge: MA.

Don, Azizah \& Yaakob. (2014). Pembentukan dan peningkatan kualiti guru di Malaysia. Siri 
monograf pendidikan. Universiti Utara Malaysia Press, Sintok.

Flynn, B. B., Schroeder, R. C., \& Sakakibaba, S. (1994). A framework for quality management research and an associated measurement instrument, Journal of Operational Management, Vol. 11, pp. 339-366.

Hanushek, E. A., \& Rivkin, S. G. (2006). Chapter 18 Teacher Quality. Handbook of the Economics of Education 2(6): 1051-1078.

Ishikawa, K. (1985). What is total quality control?The Japanese way. Prentice- Hall, London.

Juran, J. M., \& Gryna, F. M. (1993). Quality Planning and Analysis: From Product Development through Use. New York: McGraw-Hill.

Kanji, G. K., \& Asher, M. (1993). Total quality management process: A systematic approach, advance in total quality management series. Carfax: Abingdon.

Ko, W.-H., \& Chung, F.-M. (2014). Teaching Quality, Learning Satisfaction, and Academic Performance among Hospitality Students in Taiwan. World Journal of Education 4(5).

Lent, R. W., \& Brown, S. D. (2006). Integrating person and situation perspectives on work satisfaction: A social-cognitive view. Journal of Vocational Behavior 69(2): 236-247.

Mann, R. S. (1992). The development of a framework to asst in the implementation of TQM. PhD thesis. Deparment of Industrial Studies, University of Liverpool, UK.

Mau, W. J., Ellsworth, R., \& Hawley, D. (2008). Job satisfaction and career persistence of beginning teachers. The International Journal of Educational Management, 22(1), 4861.

MOE. (2007). Pekeliling kurang tugas guru 2012. Kementerian Pendidikan. 1-22.

MOE. (2008). Standard Guru Malaysia (SGM). Kementerian Pelajaran Malaysia. 1-187.

MOE. (2016). Pelan Induk Pembangunan Profesionalisme Keguruan (PIPPK). Kementerian Pendidikan Malaysia 1-53.Nilsen, Trude \& Gustafsson. (2016). Teacher Quality, Instructional Quality and Student Outcomes. New York City: Springer International Publishing.

Nordin, A. B., \& Othman, I. (2008). Falsafah Pendidikan dan Kurikulum. Tanjung Malim: Quantum Books.

Oakland, J. (2014). Total Quality Management and Operational Excellence. London: Routledge

Rahim, A., Rahman, A., \& Daud, K. (2012). Hubungan antara sistem pengurusan sekolah kualiti (SPSK) dengan kualiti dan produktiviti guru di sekolah rendah daerah Johor Bahru. Thesis (Sarjana Pendidikan (Pengurusan dan Pentadbiran) - Universiti Teknologi Malaysia, 2012. 1-20.

Shahril, M. (2005). Amalan pengajaran guru yang berkesan: Kajian di beberapa sekolah menengah di Malaysia. Jurnal Fakulti Pendidikan Universiti Malaya 1-14.

Zhang, Z., Waszink, A., \& Wijngaard, J. (2000). An instrument for measuring TQM implementation for Chinese manufacturing companies", International Journal of Quality \& Reliability Management, Vol. 17 No. 7, pp. 730-55. 